\title{
POTENTIAL OF WILD GROWING JAPANESE KNOTWEED (REYNOUTRIA JAPONICA) FOR BRIQUETTE PRODUCTION
}

\author{
Anna Brunerova, Miroslav Muller, Milan Brozek \\ Czech University of Life Sciences Prague \\ brunerova@tf.czu.cz,muller@tf.czu.cz,brozek@tf.czu.cz
}

\begin{abstract}
Popularity of renewable energies and their competitiveness with fossil fuels are rapidly increasing also due public interest in such topic as biomass, which represents $75 \%$ of all renewable resources. Therefore, much of the current literature pays particular attention to variety of biomasses, which are not publicly well-known yet. Japanese knotweed (Reynoutria japonica) is a hardy plant with outstanding biomass yield up to $30 \mathrm{t} \cdot \mathrm{ha}^{-1}$ of dry matter (i.e. $583.32 \mathrm{GJ} \cdot \mathrm{h}^{-1}$ ), however, it belongs to invasive plants, which spread rapidly $\left(>200 \mathrm{stalks} \cdot \mathrm{m}^{-2}\right.$ ), form dense monocultures and replace native vegetation. Thus, there is intensive effort to reduce its population and to prevent further spread. Considering that, a great amount of biomass with extremely high yield can be produced and utilized for energy production. The aim of the present study was to determine the potential of Japanese knotweed as a feedstock material for briquette production within its chemical, mechanical and microscopic properties. Within the chemical analysis a satisfactory level of moisture content (8.84\%), ash content (1.14\%), gross calorific value $\left(19.43 \mathrm{MJ} \cdot \mathrm{kg}^{-1}\right)$ and net calorific value $\left(17.71 \mathrm{MJ} \cdot \mathrm{kg}^{-1}\right)$ were proved. The mechanical analysis of the produced briquette samples also proved a high level of biofuel quality; mechanical durability was determined equal to $95.1 \%$, volume density equal to $989.1 \mathrm{~kg} \cdot \mathrm{m}^{-3}$ and rupture force was $112.1 \mathrm{~N} \cdot \mathrm{mm}^{-1}$. The microscopic analysis described the surface of the material and dimensions of the particle size within what it proved that $68 \%$ of the particles had the surface area $<2 \mathrm{~mm}^{2}$ and average length of the fraction size $<5 \mathrm{~mm}$ was observed in $35 \%$.Overall evaluation of all investigated parameters of Japanese knotweed exhibited more than satisfactory results. The results of this study indicate that Japanese knotweed is a crop with high energy potential.
\end{abstract}

Keywords: renewable energy, solid biofuel, biomass, invasive crop, calorific value.

\section{Introduction}

Fallopia japonica, Reynoutria japonica, Japanese knotweed, Asian knotweed, Japanese bamboo and also invasive alien plant, alien invader, alien weed and many other names are used to designate one specific plant which got into people's awareness in the last decades[1]. Attention that is devoted to Japanese knotweed is unfortunately related to its negative consequences for environment and nature biodiversity, as its designation suggests. Japanese knotweed originates from Japan and was classified in 1777 by Houttuyn. During the $19^{\text {th }}$ century this plant was brought into different parts of the world as aprized ornamental plant [2]despite the principles of biodiversity conservation. Since then this plant has spread rapidly from the initial areas of planting and nowadays it is considered as one of the world's most aggressive invasive plants causing serious damage to the local ecosystems [3; 4]. These undesirable impacts are related to the plants reproductive biology, physiology and mainly its influence on other flora and fauna. Taxonomy of the plant describes it as a perennial crop growing up to 3 meters height with thick foliage and a massive rhizome root system. Thick grown leaves create impermeable barrier of shade which makes it impossible for other vegetation to grow near the plant [5]. Moreover, the plants emit specific chemicals which attack vegetation in close areas. In Japan, the place of the plant's origin, the invasion of the plant is controlled by native plant diseases and specific insects and fungi, which consume and reduce population of the existing plant. However, there are no natural enemies for the plant in the countries of importation and the plant spreading is uncontrollable, which emphasizes the importance of biodiversity conservation principles [6].

Considering all mentioned information and the current worldwide situation there is an intensive effort to stop the expansion of the existing plant; while the most affected areas are in Europe and North America. Effort to control the plant expansion and reduction of the plant population has different forms; for instance, previous researches have proved the possibility of utilization of specific insect genus (Aphalara itadori) as a biological plant control agent with positive results [7]. Actual possibilities of the plant extermination are difficult, expensive and unreliable. The plants are characterized by strong will to live; they are resistant to chemical weed killers and even a diminutive sized fragment of the plant body or root is sufficient to form a new population of plants[1]. Consequently, the most effective way how to exterminate the present plant without its subsequent repeating growth is to burn all parts of the plant body [8; 9]. Large areas are already covered by Japanese knotweed population all over the world, which indicates that a great amount of waste 
biological materials (biomass) should be produced due to desired plant extermination. Focused on the plant energy potential the biomass yield reaches up to $15.89 \mathrm{t} \cdot \mathrm{ha}^{-1}$, which is an extremely high result value [10]. Present knowledge proves an advantage of the plant waste biomass burning(in order to exterminate the plant population)and indicates its possible utilization for directed combustion purposes, therefore, energy production purposes. Such a subsequent utilization of Japanese knotweed waste biomass ensures reliable extermination of the plant population, moreover, adds value to the produced biological wastes. A possibility of subsequent utilization of Japanese knotweed waste biomass for bio-coke (highly densified biomass briquette) production has already been investigated, while the final products demonstrated satisfactory level of the chemical and mechanical quality indicators[11]. Another research of related to the energy potential of Japanese knotweed indicated its high energy potential and satisfactory chemical composition for direct combustion purposes. In accordance to the mentioned information it can be concluded that there is a possibility of subsequent utilization of Japanese knotweed waste biomass as a feedstock for briquette fuel production due to the current plant extension, effort to exterminate already the existing plant population and the plant high biomass yield and energy potential [12].

Therefore, the main aim of the present study was to investigate and evaluate the potential of Japanese knotweed waste biomass for briquette production within determination of its quality indicators expressed by the energy potential, microscopic analysis and briquette sample mechanical and chemical properties.

\section{Materials and methods}

An experimental research was performed within the present study contained from several divided parts related to the different materials and briquette properties. Overall evaluation of all tested factors and quality indicators provided complex perspective of suitability of the investigated feedstock material, namely Japanese knotweed waste biomass, for briquette production.

\section{Material and sampling}

The investigated plants selected for the present experimental testing originated from wild growing population located in Central Bohemian Region, Czech Republic. The investigated material was harvested during the autumn harvest period, which indicated low amount of leaves in comparison with the amount of stems. Harvested and cleaned biomass material contained all over ground parts of plant bodies. Vegetation was very thick (as it is shown in Figure 1) but the stems were hollow (with different diameters), thus, the weight of the material was low.
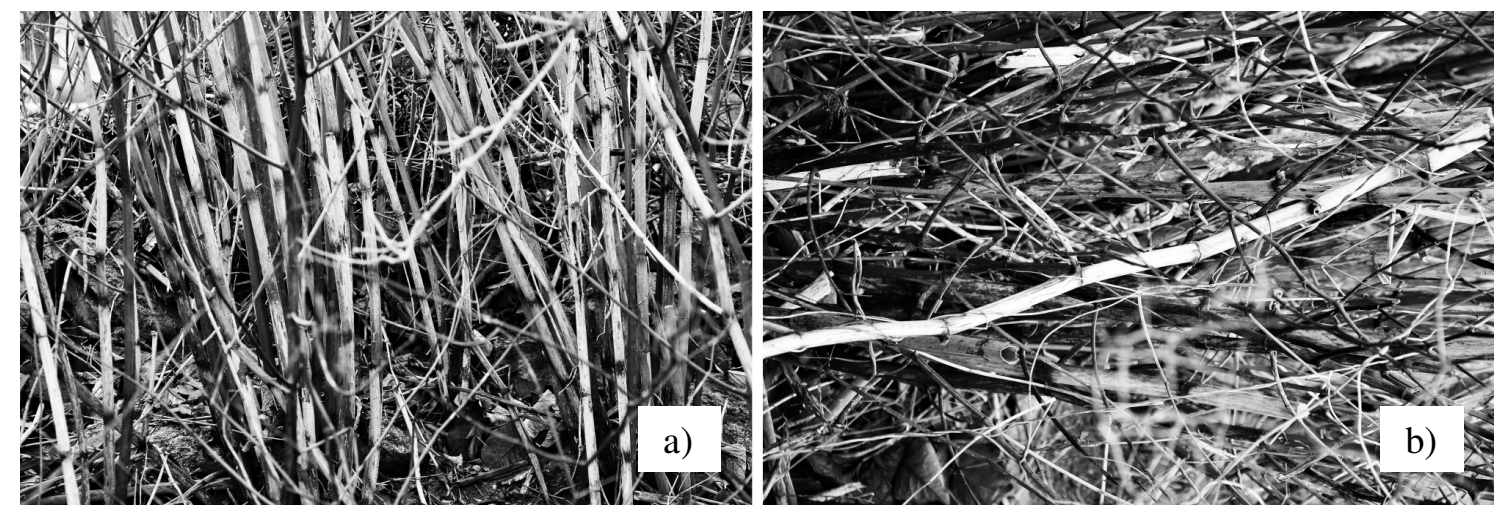

Fig. 1. Wild growing Japanese knotweed: $\mathrm{a}$ - before harvest; $\mathrm{b}$ - after harvest

Harvested biomass was milled by the electrically powered Hammer mill 9FQ - 40C (Henan, China) working with the principle of roller culling; a sieve with holes of $8 \mathrm{~mm}$ diameter was used. Subsequently, the briquette samples were produced under the same manufacturing conditions by the hydraulic piston press Briklis, type BrikStar 30-12 (Malšice city, Czech Republic). All briquette samples were cylindrically shaped with identical diameter of $50 \mathrm{~mm}$; the weight and length of the samples differed. A properly prepared feedstock material during the densification process (briquetting) 
and the produced briquette sample are shown in Figure 2. The whole process of briquette production was performed in accordance to the related mandatory technical standard EN ISO 17225-1 (2015) [13].
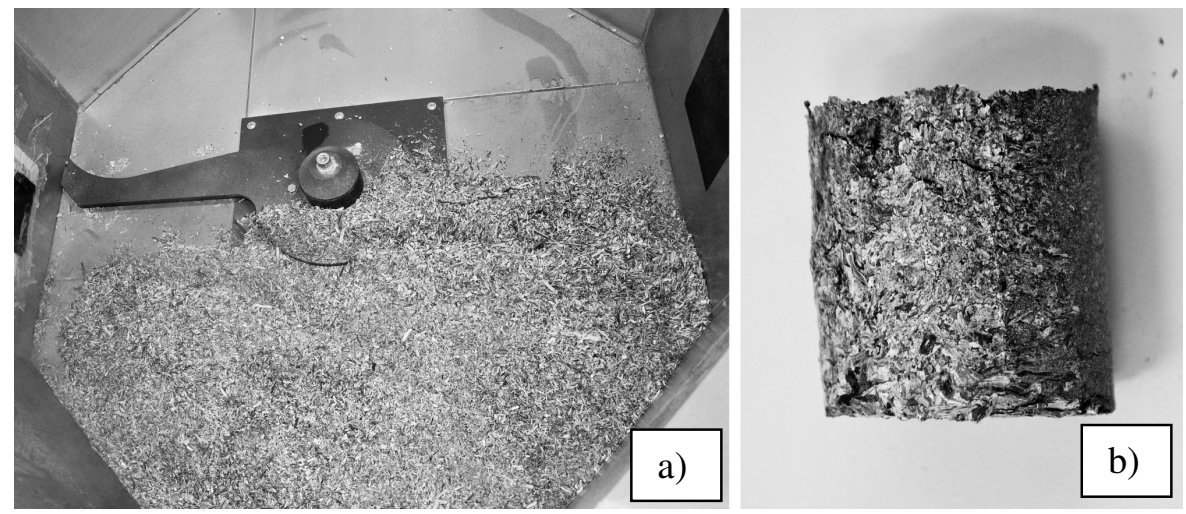

Fig. 2. Milled biomass material: $a$ - bulk form - feedstock; $b$ - densified form - briquette

\section{Experimental measurement}

Due to the determination of the chemical quality indicators the main attention was focused on the energy potential of the investigated material expressed by its calorific value $\left(\mathrm{MJ} \cdot \mathrm{kg}^{-1}\right)$. Subsequently, the moisture and ash contents were determined in attempt to describe the material burning ability and behavior during combustion. Moisture and ash contents were determined by experimental testing performed in the thermogravimetric analyzer LECO type TGA 701 (Saint Joseph, United States). The process of testing was identical with the regulations stated by the mandatory technical standards EN ISO 18122 (2015) and EN ISO 18134-2 (2015) [14; 15].Energy potential was expressed by the gross calorific value and further by the net calorific value. The first mentioned parameter was determined by the isoperibol calorimeter LECO type AC 600 (Saint Joseph, United States) in accordance to the European Standard EN 14918 (2010) [16]and the net calorific value was stated by using the calorimetric method and subsequent proper calculations; the whole process was conducted according to the European Standard ISO 1928 (2010) [17].

Analysis of the material surface, shapes and dimensions was determined by image analysis performed by the stereoscopic microscope Arsenal equipped with sensors with digital camera I Artcam 300 M. Primarily, thecross-sections of whole plant stems were monitored within the comparison of their different sizes and diameters. Secondary, properly prepared feedstock material with the particle size suitable for briquette production was subjected to measurements focused on its shape and dimension determination. The measured values were processed by evaluation software Quick PHOTO INDUSTRIAL and the solid binding between sub-parts of the investigated material was defined.

Within description of the produced briquette mechanical quality the following indicators were determined: bulk density $\left(\mathrm{kg} \cdot \mathrm{m}^{-3}\right)$, volume density $\left(\mathrm{kg} \cdot \mathrm{m}^{-3}\right)$, mechanical durability $(\%)$ and rupture force $\left(\mathrm{N} \cdot \mathrm{mm}^{-1}\right)$. Bulk density of the used feedstock material and the volume density of the produced briquette samples were determined in attempt to evaluate the efficiency of the densification process (briquetting process) expressed as a difference between these two indicators. The process of testing and subsequent calculation were performed in accordance to the related technical standards EN ISO 17225-1 (2015), EN ISO 17828 (2016) and EN 15234-1 (2011) [13; 18; 19]. Mechanical durability was considered as the main indicator of briquette mechanical quality, therefore, its determination was defined by another standard EN ISO 17831-2 (2016)[20]. The investigated briquette samples were subjected to controlled deformation by impacts in a special dustproof rotation drum powered by electricity in specific time interval. Final resistance of the briquette samples against the impacts was measured. The last performed experimental testing was rupture force testing. The present indicator is not defined by standards; the principle of plate-loading test was a measurement of the loading force, which was applied to specific briquette samples. The source or energy was ensured by the universal tensile compression testing machine type ZDM $5 \mathrm{t}$ (Dresden, Germany) working with maximal force 
$50,000 \mathrm{~N}$ and loading speed $20 \mathrm{~mm} \cdot \mathrm{min}^{-1}$. The maximal loading force before the briquette sample was irreversibly deformed was measured.

\section{Results and discussion}

The present chapter was divided into three different parts according to different characteristics of the performed experimental testing, thus, different result values were obtained and their importance and influence on the final efficiency of briquette production form Japanese knotweed waste biomass.

\section{Chemical analysis}

The result values measured and obtained during determination of the basic chemical parameters of Japanese knotweed are noted in Table 1. All selected parameters were considered as adequate quality indicators, which clearly described its suitability for direct combustion purposes in the form of briquette biofuel.

\section{Chemical composition and energy potential of investigated material}

Table 1

\begin{tabular}{|c|c|c|c|}
\hline $\begin{array}{c}\text { Moisture } \\
\text { content, \% }\end{array}$ & Ash content $\mathbf{\%}$ & $\begin{array}{c}\text { Gross calorific value, } \\
\mathbf{M J} \cdot \mathbf{k g}^{-1}\end{array}$ & $\begin{array}{c}\text { Net calorific value, } \\
\mathbf{M J} \cdot \mathbf{~ g ~}^{-1}\end{array}$ \\
\hline $11.5 \pm 2.3 \%$ & 1.14 & 19.43 & 17.71 \\
\hline
\end{tabular}

Focused on specific parameters, testing of the moisture content exhibited the final value, which was considered as the maximal suitable level. Basically, the level of the moisture content should be up to $10 \%$ for feedstock material for briquette production. Higher level of moisture content could cause problems during the briquetting process. Despite this fact, the level of the moisture content was observed at higher level than it is usual, however, no problems during the briquette production were monitored. The obtained value of the ash content expressed very low level, which is highly required. Within evaluation of the biomass ash content, it is common that herbaceous biomass exhibits higher (undesirable) level (5-10\%) in comparison with wood biomass, which exhibits the lowest level of the ash content (0.3-1\%) from all biomass kinds. It can be concluded that Japanese knotweed exhibited the ash content level closer to wood biomass despite the fact that it is herbaceous biomass. Evaluation of the calorific values obtained for the investigated material expressed high level of the present indicator of Japanese knotweeds energy potential. Both, the gross and net calorific values occurred on the level comparable with wood biomass or energy crops. Energy potential of Japanese knotweed proved its suitability for combustion properties, thus, for energy production in the form of briquette biofuel. The gross calorific value of Japanese knotweed was determined in the previous study equal to $18.4 \mathrm{MJ} \cdot \mathrm{kg}^{-1}$ [12]. The energy potential of the investigated feedstock material exceeded the energy potential of other waste biomass, namely, the gross calorific value of forest wood residues was proved equal to $18.7 \mathrm{MJ} \cdot \mathrm{kg}^{-1}$ and equal to $17.2 \mathrm{MJ} \cdot \mathrm{kg}^{-1}$ for oat grain residues [21]. However, the result value obtained within the present research was lower than Jatropha oil-cake gross calorific value $20.4 \mathrm{MJ} \cdot \mathrm{kg}^{-1}[22]$.

\section{Microscopic analysis}

Monitoring and evaluation of Japanese knotweeds properties were performed for raw form of whole plants and subsequently for processed form of the prepared feedstock material. The result values obtained during measurement of whole plant properties proved the average length of the harvested plants equal to $2.8 \pm 0.5 \mathrm{~m}$ and stated the average diameter of the stems equal to $2.8 \pm 0.6 \mathrm{~cm}$. The investigated parameters of the processed feedstock particles (size, shape and surface) were stated as important factors, which influence the whole process of densification (briquette production) and mechanical quality of final products (briquettes). The image analysis of unprocessed plant stems and milled particles is shown in Figure 3.

The first of the observed particle properties was its area expressed in $\mathrm{mm}^{2}$ within 173 measurements performed to obtain the result values. Processing and assessment of the measured values proved that the largest groups of the particle areas contained from $68 \%$ particles with area $<2$ $\mathrm{mm}^{2}$. The groups with the particle surface in the range of 3-10 $\mathrm{mm}^{2}$ were measured in $29 \%$ and rest of 
groups exhibited the particle areas $>10 \mathrm{~mm}^{2}$. Detailed description of the particle areas $\left(\mathrm{mm}^{2}\right)$ is shown in Figure 4.
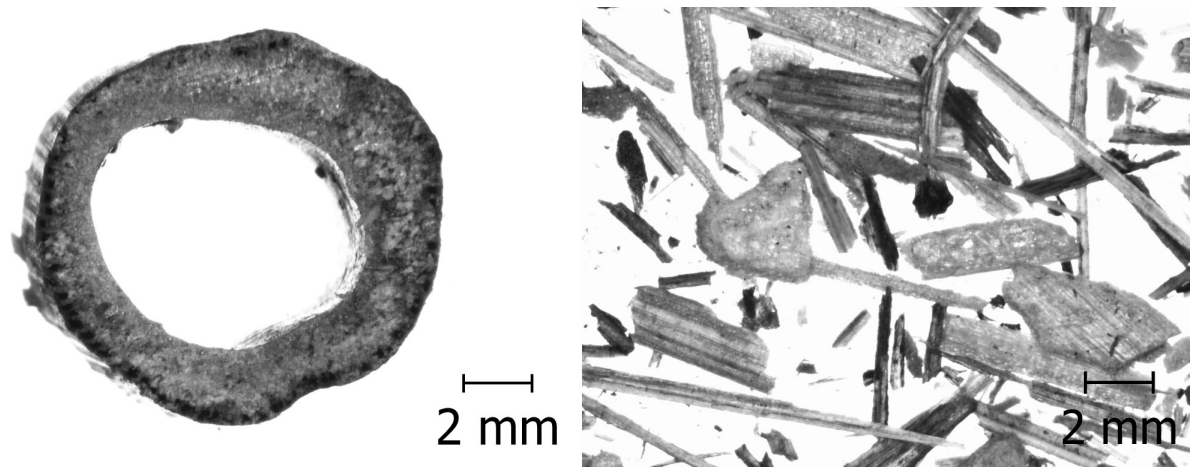

Fig. 3. Investigated feedstock material: $a$ - cross-section of stem; $b$ - feedstock particles

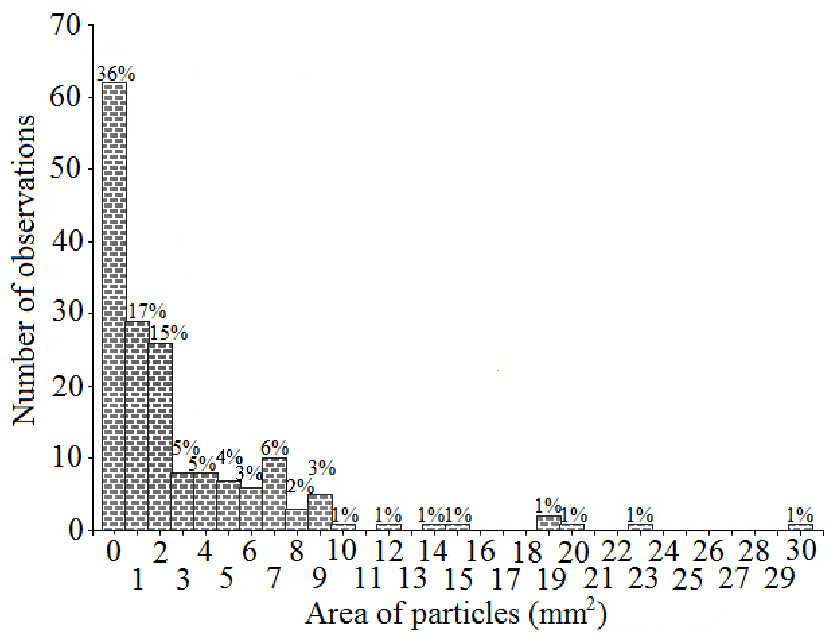

Fig. 4. Distribution of feedstock material particle size areas

The second investigated particle property was the fraction size in $\mathrm{mm}$, which was also determined by processing of 173 measurements. As it is visible from Figure 5, which describes the present issue in detail, the largest groups with the average length of the fraction size $<5 \mathrm{~mm}$ were observed in $35 \%$ of measurements, measurements of the fraction size 6-10 mm were monitored for $28 \%$ and particles with the fraction length $>10 \mathrm{~mm}$ occurred in $63 \%$.

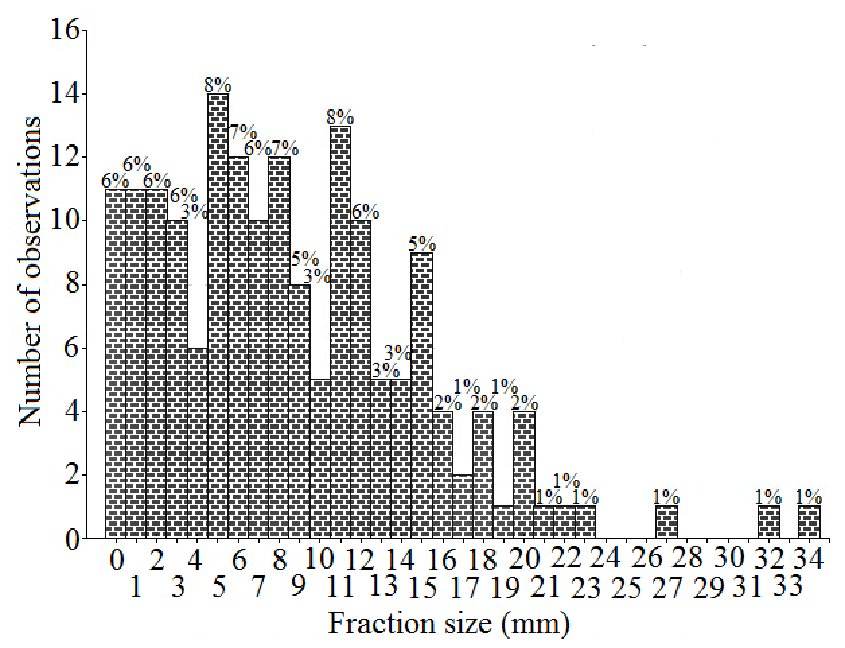

Fig. 5. Distribution of length of feedstock material fraction

The most frequent fraction size was stated for 5 and $11 \mathrm{~mm}$ groups, both were observed in $8 \%$ of measurements, followed by fraction sizes 6 and $8 \mathrm{~mm}$, which were observed for $7 \%$ of measurements. 
It can be concluded that the microscopic analysis proved that particle sizes and areas were in suitable form for briquette production.

\section{Mechanical analysis}

Overall evaluation of the final mechanical quality of the produced briquette samples indicated a satisfactory level. Comparison between the bulk density of the feedstock material and the volume density of the produced briquette samples proved that by using of the process of densification the density increased, thus, the volume decreased approximately 7.6 times, which indicated high efficiency of the densification process. The specific result values of all performed experimental tests are shown in Table 2.

Table 2

Mechanical properties of produced briquette samples

\begin{tabular}{|c|c|c|c|}
\hline $\begin{array}{c}\text { Bulk density, } \\
\mathbf{~ k g} \cdot \mathbf{m}^{-\mathbf{3}}\end{array}$ & $\begin{array}{c}\text { Volume density, } \\
\mathbf{~ k g} \cdot \mathbf{~ m}^{\mathbf{- 3}}\end{array}$ & $\begin{array}{c}\text { Mechanical durability, } \\
\mathbf{\%}\end{array}$ & $\begin{array}{c}\text { Rupture force, } \\
\mathbf{N} \cdot \mathbf{m m}^{-\mathbf{1}}\end{array}$ \\
\hline $129.5 \pm 2.8$ & $989.1 \pm 15.7$ & $95.1 \pm 0.2$ & $112.1 \pm 15.9$ \\
\hline
\end{tabular}

The level of mechanical durability corresponded to high quality of biofuel; the level of mechanical durability $>90 \%$ was proved, consequently, also the suitability of Japanese knotweed for briquette production. The mentioned level of mechanical durability $(>90 \%)$ is the required level for commercial briquette production. The measured result value was considered as good in comparison with the mechanical durability of other herbaceous biomass briquettes; the following result values were proved: $87.4 \%$ - common reed, $91.4 \%$ - reed canary grass [23], $67 \%$ - switch grass [24] or $91.45 \%$-Virginia mallow [25]. The level of rupture force was also evaluated as sufficient; detailed values and the relation between the briquette sample rupture force and volume density are shown in Figure 6.

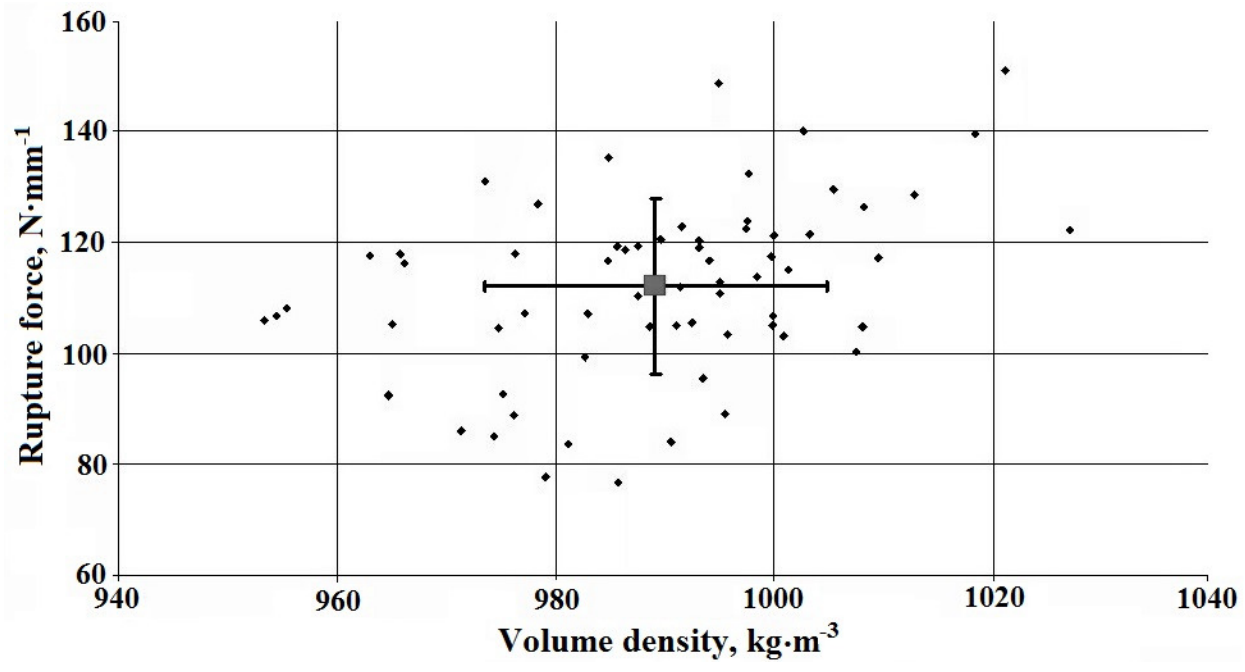

Fig. 6. Relation between rupture force and volume density of produced briquette samples

\section{Conclusions}

Considering all available information obtained during the theoretical research done within the present paper originating from previous studies it is not recommended to plant and spread Japanese Knotweed and disseminate its population beyond its natural territory, where the population is naturally controlled. At least, until a way how to control and reduce its population and how to prevent its undesirable spreading will be ensured (biological or chemicalplant control agents, genetic modification). However, suitability and potential of Japanese knotweed as a feedstock material for briquette fuel production was proved at large extent; all experimental tests performed within the chemical, mechanical and microscopic analysis expressed result values at high level. In general, it can be recommended to utilize the already existing population of Japanese Knotweed for the purpose of energy production in the form of briquette biofuels, interalia, direct combustion of plants will also 
ensure the destruction of plant seeds or residues. The present findings may influence the utilization of Japanese Knotweed waste biomass in areas where there is effort to exterminate the plant population or in areas of its natural growth.

\section{Acknowledgment}

The research was supported by Internal Grant Agency of the Faculty of Engineering, Czech University of Life Sciences Prague, grant number 2017:31140/1312/3112 and further by the Internal Grant Agency of the Czech University of Life Sciences Prague, grant number 20173005 $(31140 / 1313 / 3108)$.

\section{References}

1. Weber E., 2003. Invasive Plant Species of the World: A Reference Guide to Environmental Weeds. CABI Publishing, Wallingford, Oxon, UK.

2. Synge P.M., 1956. The Royal Horticultural Society Dictionary of Gardening. Royal Horticultural Society, Oxford, UK.

3. Topp W., Kappes H., Rogers F. Response of ground-dwelling beetle (Coleoptera) assemblages to giant knotweed (Reynoutria spp.) invasion. Biological Invasions, vol. 10, 2008, pp. 381-390.

4. Gerber E., Krebs C., Murrell C., Moretti M., Rocklin R., Schaffner U. Exotic invasive knotweeds (Fallopia spp.) negatively affect native plant and invertebrate assemblages in European riparian habitats. Biological Conservation, vol. 141, 2008, pp. 646-654.

5. Beerling D.J., Bailey J.P., Conolly A.P. Fallopia japonica (Houtt.); Ronse Decraene (Reynoutria japonica Houtt; Polygonum cuspidatum Sieb. and Zucc.). Journal of Ecology, vol. 82, 1994, pp. 959-979.

6. Hollingsworth M.L., Bailey J.P. Evidence for massive clonal growth in the invasive weed Fallopia japonica (Japanese Knotweed). Botanical Journal of the Linnean Society, vol. 133 (4), 2000, pp. 463-472.

7. Shaw R.H., Bryner S., Tanner R. The life history and host range of the Japanese knotweed psyllid, Aphalara itadori Shinji: Potentially the first classical biological weed control agent for the European Union. Biological Control, vol. 49, 2009, pp. 105-113.

8. Smith J.M.D., Ward J.P., Child L.E., Owen M.R. A simulation model of rhizome networks for Fallopia japonica (Japanese knotweed) in the United Kingdom. Ecological Modelling, vol. 200, 2007, pp. 421-432.

9. Urgenson L.S., Reichard S.H., Halpern CH.B. Community and ecosystem consequences of giant knotweed (Polygonum sachalinense) invasion into riparian forests of western Washington, USA. Biological Conservation, vol. 142, 2009, pp. 1536-1541.

10. Sukopp H., Starfinger U. Reynoutria sachalinensis in Europe, and in the Far East: a comparison of the species ecology in its native, and adventive distribution range. In: Pysek, P., Prach, M., Rejmanek, M., Wade, P.M. (Eds.), Plant Invasions - General Aspects and Special Problems. Academic Publishing, Amsterdam, 1995, pp. 151-159.

11. Ito H., Sakai Y., Ida T., Nakamura Y., Fujita O. Combustion of Bio-Coke (Highly Densified Biomass Fuel) Block in High-Temperature Air Flow. ASME. ASME/JSME Thermal Engineering Joint Conference, ASME/JSME $20118^{\text {th }}$ Thermal Engineering Joint Conference.

12. Strašil Z., Kára J. Study of knotweed (Reynoutria) as possible phytomass resource for energy and industrial utilization. Research in Agricultural Engineering, vol. 56, 2010, pp. 85-91.

13. EN ISO 17225-1 (2015): Solid biofuels - Fuel specifications and classes - Part 1: General requirements.

14. EN ISO 18122 (2015): Solid biofuels - Determination of ash content.

15. EN ISO 18134-2 (2015): Solid biofuels - Determination of moisture content - Oven dry method Part 2: Total moisture - Simplified method.

16. EN 14918 (2010): Solid biofuels - Determination of calorific value.

17. ISO 1928 (2010): Solid mineral fuels - Determination of gross calorific value by the bomb calorimetric method and calculation of net calorific value.

18. EN ISO 17828 (2016): Solid biofuels - Determination of bulk density. 
19. EN ISO 17225-1 (2015): Solid biofuels - Fuel specifications and classes - Part 1: General requirements.

20. EN 15234-1 (2011): Solid biofuels - Fuel quality assurance - Part 1: General requirements.

21. EN ISO 17831-2 (2016): Solid biofuels - Determination of mechanical durability of pellets and briquettes - Part 2: Briquettes.

22. Malaták J., Passian L. Heat-emission analysis of small combustion equipments for fiomass. Research in Agricultural Engineering, vol. 57(2), 2011, pp. 37-50.

23. Ružbarský J., Müller M., Hrabě P. Analysis of physical and mechanical properties and of gross calorific value of Jatropha curcas seeds and waste from pressing process. Agronomy Research, vol. 12(2), 2014, pp. 603-610.

24. Repsa E., Kronbergs E., Pudans E. Durability of compacted energy crop biomass. Engineering for Rural Development, vol. 13, 2014, pp. 436-439.

25. Kaliyan N., Morey R.V. Factors affecting strength and durability of densified biomass products. Biomass and Bioenergy, vol. 33(3), 2009, pp. 337-359.

26. Kowalczyk-Juśko A., Kulig R., Laskowski J. The influence of moisture content of selected energy crops on the briquetting process parameters. In: Commission Of Motorization And Power Industry In Agriculture And The Volodymir Dahl East-Ukrainian National University Of Lugansk. Lublin: Polska Akademia Nauk Oddziaà W Lublinie Wschodnioukraiēski Narodowy Uniwersytet Im. 2011, pp. 189-196. 